\title{
The recombinant expression systems for structure determination of eukaryotic membrane proteins
}

\author{
Yuan $\mathrm{He}^{1,2}$, Kan Wang ${ }^{3}$, Nieng Yan ${ }^{1,2 \bowtie}$ \\ ${ }^{1}$ State Key Laboratory of Bio-membrane and Membrane Biotechnology, Tsinghua university, Beijing 100084, China \\ ${ }^{2}$ Center for Structural Biology, School of Medicine, Tsinghua university, Beijing 100084, China \\ ${ }^{3}$ China-Japan Friendship Hospital, Beijing 100029, China \\ $\triangle$ Correspondence: nyan@tsinghua.edu.cn (N. Yan) \\ Received May 16, 2014 Accepted June 16, 2014
}

\begin{abstract}
Eukaryotic membrane proteins, many of which are key players in various biological processes, constitute more than half of the drug targets and represent important candidates for structural studies. In contrast to their physiological significance, only very limited number of eukaryotic membrane protein structures have been obtained due to the technical challenges in the generation of recombinant proteins. In this review, we examine the major recombinant expression systems for eukaryotic membrane proteins and compare their relative advantages and disadvantages. We also attempted to summarize the recent technical strategies in the advancement of eukaryotic membrane protein purification and crystallization.
\end{abstract}

KEYWORDS eukaryotic membrane proteins, recombinant expression, structural biology, integral membrane proteins (IMPs), fluorescence detected size exclusion chromatography (FSEC), protein purification and crystallization

\section{INTRODUCTION}

It is estimated that approximately $30 \%$ of the protein-coding genes are for integral membrane proteins (IMPs) in human (Overington et al., 2006; Murray et al., 2012). IMPs are critical players for many important physiological processes including metabolism, signal transduction, and energy conversion and utilization (Krogh et al., 2001). Aberrant expressions and activities of IMPs are associated with a variety of diseases such as cancer, Alzheimer's disease, and metabolic diseases (Ishikawa et al., 2004; Sanders and Myers, 2004; Overington et al., 2006; Aisenbrey et al., 2008; Bkaily and Al-Khoury, 2014). IMPs constitute more than $50 \%$ of the US Food and Drug Administration (FDA)approved drug targets (Russell and Eggleston, 2000; Yildirim et al., 2007). Structures of eukaryotic membrane proteins are actively pursued for structure-based drug development.

In contrast to their physiological and pathophysiological significance, the progress on the structure biology of IMPs, particularly eukaryotic IMPs, has been relatively slow. By the end of March 2014, in total 466 unique membrane protein structures have been reported (Snider and Stephen, 2014), the majority of which are of prokaryotic origins. With respect to eukaryotic IMPs, more than half of the determined structures are for proteins obtained from endogenous sources (Bill et al., 2011). These proteins, exemplified by the electron transport chain complexes (Tsukihara et al., 1996; Xia et al., 1997; Sun et al., 2005), ATP synthases (Abrahams et al., 1994; Liu et al., 2004; Amunts et al., 2007), and photosystems (Kurisu et al., 2003; Liu et al., 2004; Amunts et al., 2007), usually exist in abundance and are biochemically stable, hence representing ideal candidates for structural analysis. However, the total types of endogenously abundant eukaryotic IMPs are limited. The majority of IMPs exist in low copies in the host species. Therefore, structural determination of most eukaryotic IMPs requires recombinant expression of the target proteins. The first atomic-resolution structure of a eukaryotic IMP obtained through recombinant expression, Kv1.2, was reported in 2005 (Long et al., 2005). Ever since, less than seventy structures have been obtained for eukaryotic IMPs generated through recombinant expression systems (Fig. 1). 


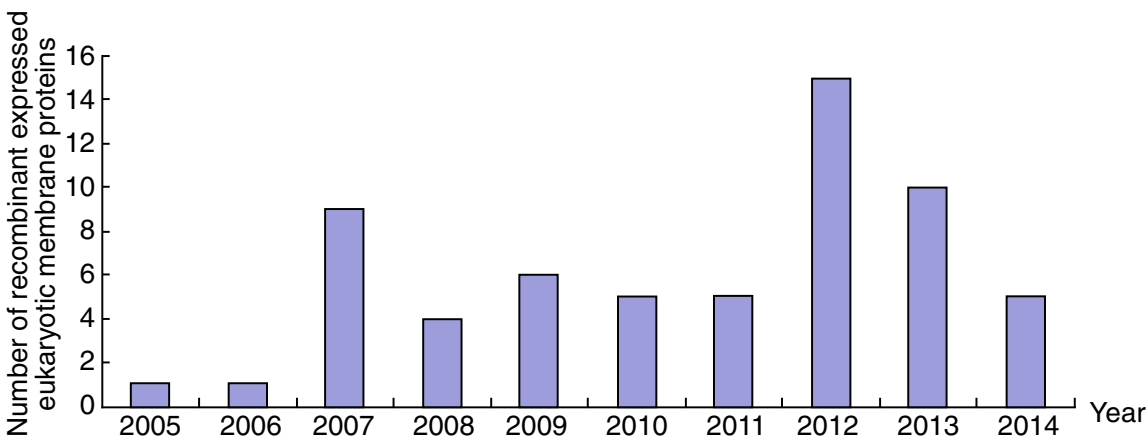

Figure 1. The development trends in recombinant expression eukaryotic membrane proteins. The structure number of eukaryotic membrane protein is limited by some obstacles such as low yield and instability in detergents. Since the first eukaryotic membrane protein structure was determined in 2005 , over sixty structures have been emerged until now.

Out of the many challenges facing structural study of eukaryotic IMPs, production of sufficient quantities of wellbehaved recombinant proteins represents the real technical bottleneck. Embedded in lipid bilayers, the structural integrity and proper functions of IMPs rely on the interactions with surrounding lipids (Phillips et al., 2009), which stabilize membrane proteins, provide lattice contacts, and in some occasions function as indispensable co-factors (van Meer et al., 2008). Recombinant expression of membrane proteins therefore requires a proper membrane environment. Whereas Escherichia coli proved to be the best host for most of prokaryotic IMPs of known structures, eukaryotic IMPs, with very few exceptions, requires eukaryotic expression systems including yeast, baculovirus-infected insect cells, and mammalian cells (Bill et al., 2011; Snider and Stephen, 2014).

In this review, in the hope of extracting some general principles on the expression and crystallization of eukaryotic membrane proteins, we examine the expression systems for the eukaryotic IMPs whose structures are obtained, attempt to summarize and compare the advantages and disadvantages of the representative recombinant expression systems, and delineate the detailed information in eukaryotic membrane protein purification and crystallization (Table 1).

\section{RECOMBINANT EXPRESSION SYSTEMS FOR EUKARYOTIC MEMBRANE PROTEINS}

The recombinantly expressed eukaryotic IMPs of known structures were obtained from four systems: $E$. coli, yeasts (Pichia Pastoris and Saccharomyces cerevisiae), insect cells, and mammalian cells. These expression systems have their respective advantages and disadvantages. The choice of an appropriate expression system remains empirical, largely depending on the biochemical and biological properties of the target proteins (Bernaudat et al., 2011). Among the recombinantly expressed eukaryotic IMPs whose structures have been solved, 4 were expressed in E. coli, 20 in yeast,
35 in insect cells, and 3 in mammalian cells. Below we will discuss these four expression systems.

\section{E. coli}

As the most frequently exploited recombinant expression system, E. coli BL21 (DE3) has the obvious advantage of rapid replication, time-saving operation, inexpensive cost, and mature and easy genetic manipulations (Sahdev et al., 2008). E. coli C43 (DE3) and C41 (DE3) strains were developed for over-expression of membrane proteins (Miroux and Walker, 1996; Dumon-Seignovert et al., 2004). Indeed, these $E$. coli strains were employed to over-express the large majority of prokaryotic IMPs whose structures were finally obtained. However, as the prokaryotic expression systems, they may lack the essential lipids, molecular chaperons, and post-translational modifications that are required for the correct membrane insertion, folding, and function of eukaryotic IMPs (Sahdev et al., 2008). As a result, only 4 structures were obtained for eukaryotic IMPs expressed in E. coli (Table 2). Despite the challenge to express eukaryotic membrane proteins in E. coli, researchers attempted to overcome these hurdles with codon-optimization (Burgess-Brown et al., 2008) and protein fusion with Mistic or GlpF tag to promote protein expression (AegeanSoftware, 2005; Drew et al., 2006; Neophytou et al., 2007), and co-expression of post-translational machineries to facilitate protein folding (Mironova et al., 2005; Mijakovic et al., 2006). Regardless of the effort, E. coli may not be an ideal system for eukaryotic IMP expression.

\section{Yeast}

Among the many yeast species, Pichia Pastoris (Pichia) and Saccharomyces cerevisiae (S. cerevisiae), which have been genetically well characterized, are the major systems to overexpress eukaryotic IMPs (Strausberg and Strausberg, 2001; Bornert et al., 2012). Schizosaccharomyces pombe is also employed for overexpression of IMPs, but not as widely 


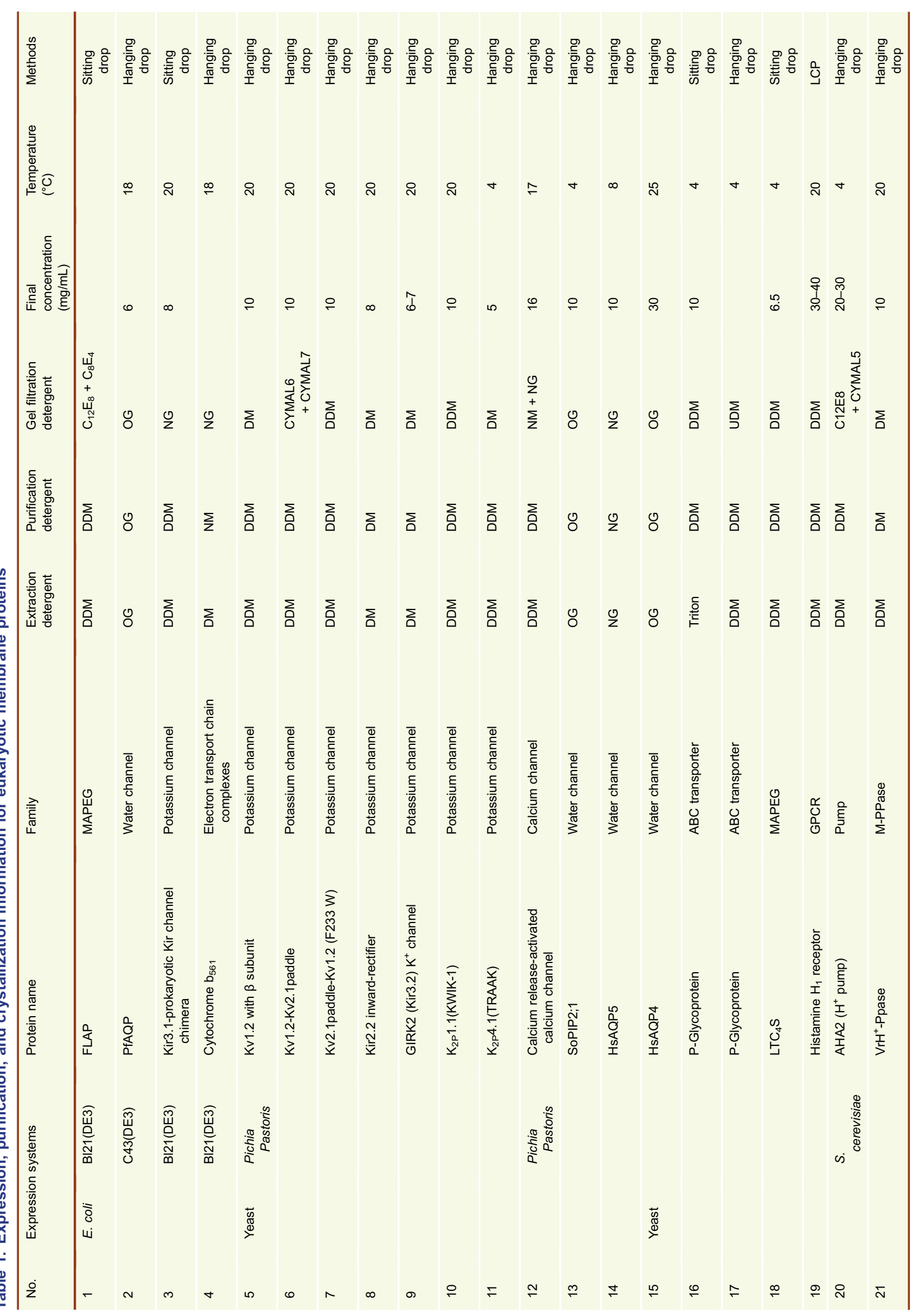




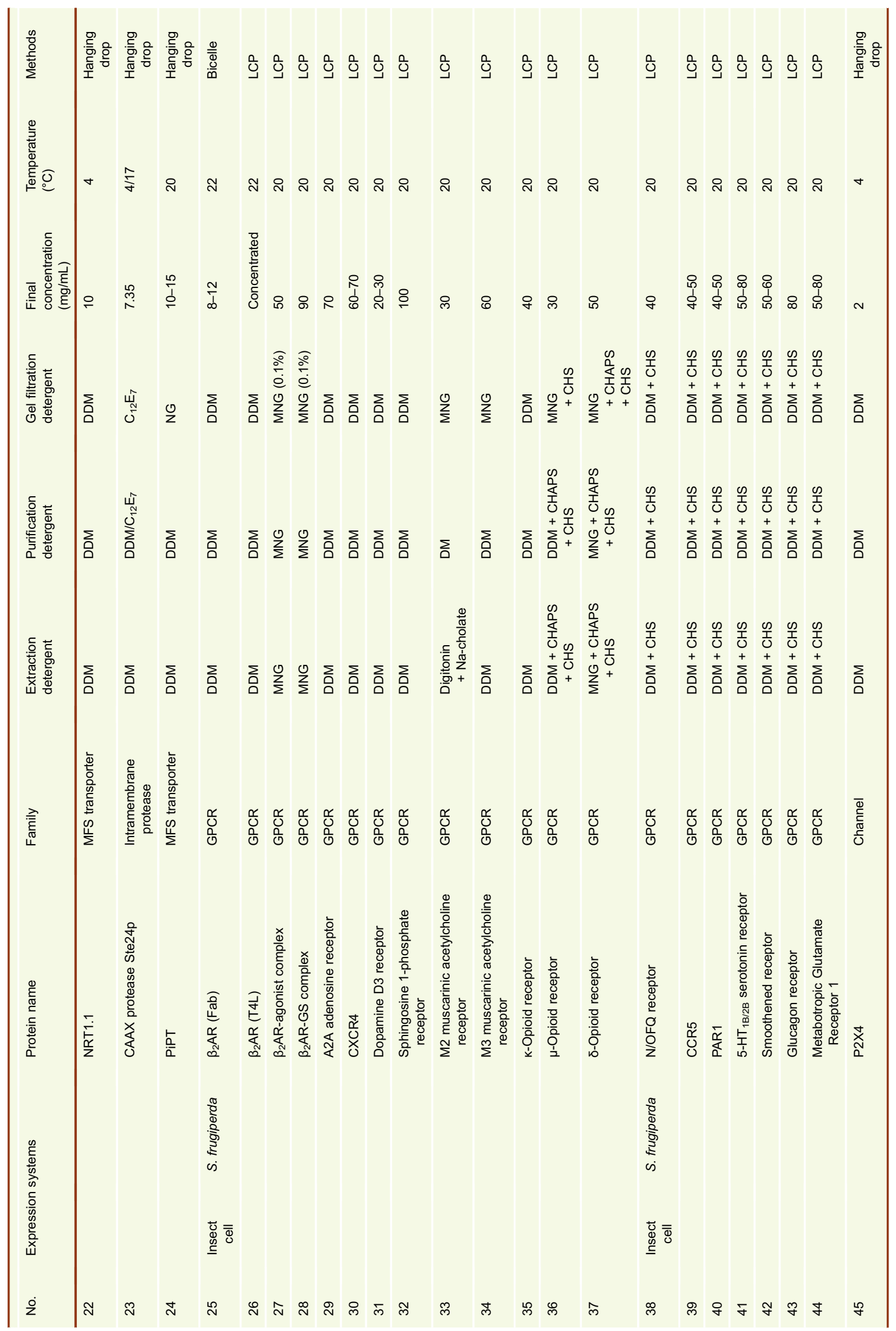




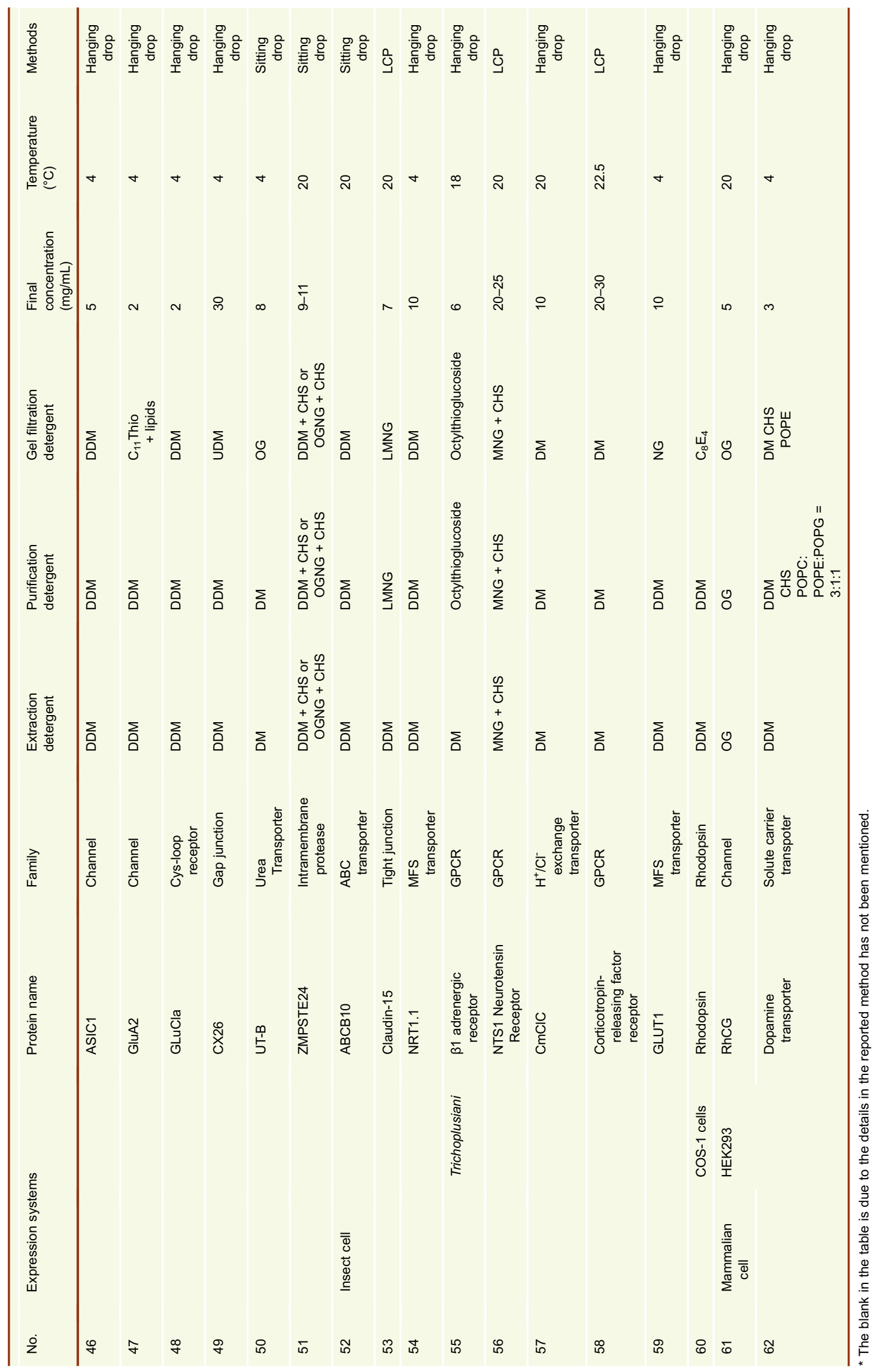


Table 2. E. coli as an expression system for eukaryotic membrane protein

\begin{tabular}{|c|c|c|c|c|c|c|}
\hline \multicolumn{2}{|c|}{ Expression systems } & \multirow{2}{*}{$\begin{array}{l}\text { No. } \\
1\end{array}$} & \multirow{2}{*}{$\begin{array}{l}\text { Protein } \\
\text { FLAP }\end{array}$} & \multirow{2}{*}{$\begin{array}{l}\text { Species } \\
\text { Homo sapiens }\end{array}$} & \multirow{2}{*}{$\begin{array}{l}\text { PDB code } \\
\text { 2Q7 M 2Q7R }\end{array}$} & \multirow{2}{*}{$\begin{array}{l}\text { Reference } \\
\text { Ferguson et al., } 2007\end{array}$} \\
\hline E. coli & BI21(DE3) & & & & & \\
\hline & C43 (DE3) & 2 & PfAQP & Plasmodium falciparum & $3 \mathrm{CO} 2$ & Newby et al., 2008 \\
\hline & $\mathrm{BI} 21(\mathrm{DE} 3)$ & 3 & $\begin{array}{l}\text { Kir3.1-prokaryotic Kir } \\
\text { channel chimera }\end{array}$ & Streptomyces lividans & 2QKS & Nishida et al., 2007 \\
\hline & $\mathrm{BI} 21(\mathrm{DE} 3)$ & 4 & Cytochrome $b_{561}$ & Arabidopsis thaliana & $\begin{array}{l}\text { 4O6Y, 4O79, } \\
\text { 4O7G }\end{array}$ & Lu et al., 2014 \\
\hline
\end{tabular}

Table 3. Yeast as an expression system for eukaryotic membrane protein*

\begin{tabular}{|c|c|c|c|c|c|c|}
\hline \multicolumn{2}{|c|}{ Expression systems } & \multirow{2}{*}{ No. } & \multirow{2}{*}{$\begin{array}{l}\text { Protein } \\
\text { Kv1.2 with } \beta \text { subunit }\end{array}$} & \multirow{2}{*}{$\begin{array}{l}\text { Species } \\
\text { Drosophila } \\
\text { melanogaster }\end{array}$} & \multirow{2}{*}{$\begin{array}{l}\text { PDB code } \\
2 \text { A79 }\end{array}$} & \multirow{2}{*}{$\begin{array}{l}\text { Reference } \\
\text { Long et al., } 2005\end{array}$} \\
\hline Yeast & $\begin{array}{l}\text { Pichia } \\
\text { Pastoris }\end{array}$ & & & & & \\
\hline & & 2 & Kv1.2-Kv2.1 paddle & Rattus norvegicus & 2R9R & Long et al., 2007 \\
\hline & & 3 & Kv2.1paddle-Kv1.2 (F233 W) & Rattus norvegicus & 3LNM & Tao et al., 2010 \\
\hline & & 4 & Kir2.2 Inward-Rectifier & Gallus gallus & 3JYC & Tao et al., 2009 \\
\hline & & 5 & GIRK2 (Kir3.2) channel & Mus musculus & $3 S Y O$ & $\begin{array}{l}\text { Whorton and } \\
\text { MacKinnon, } 2011\end{array}$ \\
\hline & & 6 & $\mathrm{~K}_{2 \mathrm{P}} 1.1(\mathrm{KWIK}-1)$ & Homo sapiens & $3 \mathrm{UKM}$ & $\begin{array}{l}\text { Miller and Long, } \\
2012\end{array}$ \\
\hline & & 7 & $\mathrm{~K}_{2 \mathrm{P}} 4.1$ (TRAAK) & Homo sapiens & 3UM7 & Brohawn et al., 2012 \\
\hline & & 8 & $\begin{array}{l}\text { Calcium release-activated } \\
\text { calcium channel }\end{array}$ & $\begin{array}{l}\text { Drosophila } \\
\text { melanogaster }\end{array}$ & 4HKR & Xiaowei Hou, 2012 \\
\hline & & 9 & SoPIP2;1 & Spinacia oleracea & $1 \mathrm{Z98} 2 \mathrm{~B} 5 \mathrm{~F}$ & $\begin{array}{l}\text { Tornroth-Horsefield } \\
\text { et al., } 2006\end{array}$ \\
\hline & & 10 & HsAQP5 & Homo sapiens & 3D9S & $\begin{array}{l}\text { Horsefield et al., } \\
2008\end{array}$ \\
\hline & & 11 & HsAQP4 & Homo sapiens & 3GD8 & Ho et al., 2009 \\
\hline & & 12 & P-Glycoprotein & M. musculus & $\begin{array}{c}3 \mathrm{G} 5 \mathrm{U}, \\
3 \mathrm{G} 60 \\
3 \mathrm{G} 61\end{array}$ & Aller et al., 2009 \\
\hline & & 13 & P-Glycoprotein & $\begin{array}{l}\text { Caenorhabditis } \\
\text { elegans }\end{array}$ & $4 \mathrm{~F} 4 \mathrm{C}$ & Jin et al., 2012 \\
\hline & & 14 & LTC4S & Homo sapiens & $2 \mathrm{PNO}$ & Ago et al., 2007 \\
\hline & & 15 & Histamine $\mathrm{H}_{1}$ receptor & Homo sapiens & 3RZE & $\begin{array}{l}\text { Shimamura et al., } \\
2011\end{array}$ \\
\hline & S. cerevisiae & 16 & AHA2 (H+ pump) & $\begin{array}{l}\text { Arabidopsis } \\
\text { thaliana }\end{array}$ & 3B8C & $\begin{array}{l}\text { Pedersen et al., } \\
2007\end{array}$ \\
\hline & & 17 & VrH+-Ppase & Vigna radiata & $4 \mathrm{~A} 01$ & Lin et al., 2012 \\
\hline & & 18 & NRT1.1 & $\begin{array}{l}\text { Arabidopsis } \\
\text { thaliana }\end{array}$ & $4 C L 4$ & $\begin{array}{l}\text { Parker and } \\
\text { Newstead, } 2014\end{array}$ \\
\hline & & 19 & CAAX protease Ste $24 p$ & $\begin{array}{l}\text { Saccharomyces } \\
\text { mikatae }\end{array}$ & 4IL3 & Pryor et al., 2013 \\
\hline & & 20 & PiPT & $\begin{array}{l}\text { Piriformospora } \\
\text { indica }\end{array}$ & 4J05 & $\begin{array}{l}\text { Pedersen et al., } \\
2013\end{array}$ \\
\hline
\end{tabular}

${ }^{*}$ For some proteins like GPCR and potassium channel, only the representative ones are listed. 
Table 4. Insect cell as an expression system for eukaryotic membrane protein*

\begin{tabular}{|c|c|c|c|c|c|c|}
\hline \multicolumn{2}{|c|}{ Expression systems } & \multirow{2}{*}{ No. } & \multirow{2}{*}{$\begin{array}{l}\text { Protein } \\
\beta_{2} \mathrm{AR}(\mathrm{Fab})\end{array}$} & \multirow{2}{*}{$\begin{array}{l}\text { Species } \\
\text { Homo sapiens }\end{array}$} & \multirow{2}{*}{$\begin{array}{l}\text { PDB code } \\
\text { 2R4R 2R4S }\end{array}$} & \multirow{2}{*}{$\begin{array}{l}\text { Reference } \\
\text { Rasmussen et al., } 2007\end{array}$} \\
\hline Insect & S. frugiperda & & & & & \\
\hline & & 2 & $\beta_{2} A R(T 4 L)$ & Homo sapiens & $2 \mathrm{RH} 1$ & Cherezov et al., 2007 \\
\hline & & 3 & $\beta_{2} A R$-agonist complex & Homo sapiens & 3PDS & Rosenbaum et al., 2011 \\
\hline & & 4 & $\beta_{2}$ AR-GS complex & Homo sapiens & $3 S N 6$ & $\begin{array}{l}\text { Rasmussen et al., } \\
\text { 2011a, b }\end{array}$ \\
\hline & & 5 & $\mathrm{~A}_{2 \mathrm{~A}}$ adenosine receptor & Homo sapiens & 3EML & Jaakola et al., 2008 \\
\hline & & 6 & CXCR4 & Homo sapiens & $\begin{array}{l}\text { 3ODU } \\
\text { 3OE8 }\end{array}$ & Wu et al., 2010 \\
\hline & & 7 & Dopamine D3 receptor & Homo sapiens & 3PBL & Chien et al., 2010 \\
\hline & & 8 & $\begin{array}{l}\text { Sphingosine 1-phosphate } \\
\text { receptor subtype } 1\end{array}$ & Homo sapiens & $\begin{array}{r}3 \mathrm{~V} 2 \mathrm{~W} \\
3 \mathrm{~V} 3 \mathrm{Y}\end{array}$ & Hanson et al., 2012 \\
\hline & & 9 & $\begin{array}{l}\text { M2 muscarinic } \\
\text { acetylcholine receptor }\end{array}$ & Homo sapiens & 3UON & Haga et al., 2012 \\
\hline & & 10 & $\begin{array}{l}\text { M3 muscarinic } \\
\text { acetylcholine receptor }\end{array}$ & Rattus norvegicus & 4DAJ & Kruse et al., 2012 \\
\hline & & 11 & к-Opioid receptor & Homo sapiens & 4DJH & Wu et al., 2012 \\
\hline & & 12 & $\mu$-Opioid receptor & Mus musculus & $4 \mathrm{DKL}$ & Manglik et al., 2012 \\
\hline & & 13 & $\delta$-Opioid receptor & Mus musculus & 4EJ4 & Granier et al., 2012 \\
\hline & & 14 & N/OFQ receptor & Homo sapiens & 4EA3 & Thompson et al., 2012 \\
\hline & & 15 & CCR5 & Homo sapiens & 4MBS & Tan et al., 2013 \\
\hline & & 16 & PAR1 & Homo sapiens & 3VW7 & Zhang et al., 2012 \\
\hline & & 17 & $\begin{array}{l}5-\mathrm{HT}_{1 \mathrm{~B} / 2 \mathrm{~B}} \text { serotonin } \\
\text { receptor }\end{array}$ & Homo sapiens & 4IAR 4IB4 & $\begin{array}{l}\text { Wang et al., 2013a, b; } \\
\text { Wacker et al., } 2013\end{array}$ \\
\hline & & 18 & Smoothened receptor & Homo sapiens & 4JKV & Wang et al., 2013a, b \\
\hline & & 19 & Glucagon receptor & Homo sapiens & 4L6R & Siu et al., 2013 \\
\hline & & 20 & $\begin{array}{l}\text { Metabotropic glutamate } \\
\text { receptor1 }\end{array}$ & Homo sapiens & 4OR2 & Wu et al., 2014 \\
\hline & & 21 & $\mathrm{P} 2 \mathrm{X}_{4}$ & $\begin{array}{l}\text { Danio rerio } \\
\quad \text { (Zebra fish) }\end{array}$ & $\begin{array}{l}315 \mathrm{D} 3 \mathrm{H} 9 \mathrm{~V} \\
4 \mathrm{DW} 1\end{array}$ & $\begin{array}{l}\text { Kawate et al., 2009; } \\
\text { Hattori and Gouaux, } \\
2012\end{array}$ \\
\hline & & 22 & ASIC1 & Gallus gallus & 2QTS 3HGC & $\begin{array}{l}\text { Jasti et al., 2007; } \\
\text { Gonzales et al., } 2009\end{array}$ \\
\hline & & 23 & GluA2 & Rat & 3KG2 3KGC & Sobolevsky et al., 2009 \\
\hline & & 24 & GLuCla & $\begin{array}{l}\text { Caenorhabditis } \\
\text { elegans }\end{array}$ & $\begin{array}{l}\text { 3RHW, 3RIF, } \\
\text { 3RI5 3RIA }\end{array}$ & Hibbs and Gouaux, 2011 \\
\hline & & 25 & $\mathrm{CX} 26$ & Homo sapiens & $2 Z W 3$ & Maeda et al., 2009 \\
\hline & & 26 & UT-B & Bos taurus & $\begin{array}{l}\text { 4EZC } \\
4 E Z D\end{array}$ & Levin et al., 2012 \\
\hline & & 27 & ZMPSTE24 & Homo sapiens & 4AW6 & Quigley et al., 2013 \\
\hline & & 28 & ABCB10 & Homo sapiens & 4AYT & Shintre et al., 2013 \\
\hline & & 29 & Caludin-15 & Mus Musculus & 4P79 & Suzuki et al., 2014 \\
\hline & & 30 & NRT1.1 & Arabidopsis thaliana & $4 \mathrm{OH} 3$ & Sun et al., 2014 \\
\hline & Trichoplusia ni & 31 & $\beta 1$ adrenergic receptor & Meleagris gallopavo & 2VT4 & Warne et al., 2008 \\
\hline & & 32 & $\begin{array}{l}\text { NTS1 Neurotensin } \\
\text { Receptor }\end{array}$ & Rattus norvegicus & 4GRV & White et al., 2012 \\
\hline & & 33 & $\mathrm{CmClC}$ & $\begin{array}{l}\text { Cyanidios- } \\
\text { chyzonmerolae }\end{array}$ & 3ORG & Feng et al., 2010 \\
\hline & & 34 & $\begin{array}{l}\text { Corticotropin-releasing } \\
\text { factor receptor }\end{array}$ & Homo sapiens & $4 \mathrm{~K} 5 \mathrm{Y}$ & Hollenstein et al., 2013 \\
\hline & & 35 & GLUT1 & Homo sapiens & 4PYP & Deng et al., 2014 \\
\hline
\end{tabular}

\footnotetext{
${ }^{*}$ For some proteins like GPCR and potassium channel, only the representative ones are listed.
} 
Table 5. Mammalian cell as an expression system for eukaryotic membrane protein

\begin{tabular}{|c|c|c|c|c|c|c|}
\hline \multicolumn{2}{|c|}{ Expression system } & No. & Protein & Species & PDB code & Reference \\
\hline \multirow[t]{3}{*}{ Mammalian } & HEK293 & 1 & Rodopsin & Homo sapiens & $2 J 4 Y$ & Standfuss et al., 2007 \\
\hline & & 2 & RhCG & Homo sapiens & 3HD6 & Gruswitz et al., 2010 \\
\hline & & 3 & Dopamine transporter & Homo sapiens & $4 \mathrm{M} 48$ & Penmatsa et al., 2013 \\
\hline
\end{tabular}

Table 6. Comparison among four expression system

\begin{tabular}{lllll}
\hline & E. coli & Yeast (Pichia) & Insect cell (Sf9) & Mammalian cell (HEK293) \\
\hline Duration time before cell cultivation (Days) & $3-5$ & $6-8$ & $25-30$ & Transient: 3-5 Stable: at least 30 \\
Cell cultivation time for 1L test (Days) & $1-2$ & $3-7$ & $2-4$ & $2-4$ \\
Cost for 1L test (\$) in China & $15-20$ & $20-25$ & $200-250$ & $200-250$ \\
Number of available eukaryotic IMP structures & 4 & 20 & 34 & 3 \\
\hline
\end{tabular}

as Pichia and S. cerevisiae (Yang et al., 2009). During the past thirty years, yeast has proved to be a useful expression system: 15 eukaryotic IMP structures have been determined for proteins expressed in Pichia expression system and 5 by S. cerevisiae. Most of the structurally available eukaryotic channels such as potassium channels and water channels were expressed in yeast, as listed in Table 3.

Pichia is considered the best expression system among yeast species (Cereghino and Cregg, 2000). Several elements contribute to its increasing applications, including the simplicity of genetic manipulation, the high yield of heterologous protein, the cost-effective chemical reagents, as well as the ability of post-translational modifications (Macauley-Patrick et al., 2005). For these reasons, Pichia is a more suitable expression system for producing eukaryotic IMP than $E$. coli. Pichia shares the advantage of the molecular and genetic manipulation with $S$. cerevisiae, yet it adds extra advantage of 10- to 100- fold biomass out of the same cultural volume comparing with S. cerevisiae (Macauley-Patrick et al., 2005).

The improved techniques and the commercial availability together promote the development of Pichia (Cereghino and Cregg, 2000). Pichia is a methylotrophic yeast, capable of utilizing methanol as its sole carbon source (Yurimoto and Sakai, 2009). A promoter derived from the alcohol oxidase I $(A O X I)$, which is the first-step enzyme in the methanol metabolism, strictly controls the expression of the foreign proteins (Macauley-Patrick et al., 2005). The commercial vector $\mathrm{pPICZ}$ (or $\mathrm{pPICZ \alpha}$ ) takes advantage of the AOXI promoter, being induced by methanol (Li et al., 2007). AOXI promoter is prevailing than other promoters like PMA1 and GPD1 for its strong and highly inducible ability (Cereghino and Cregg, 2000). After the vector is readily prepared and transformed into the competent cells, the target gene can be inserted into the Pichia genome in high efficiency via homologous recombination to generate stable cell lines, and then the colonies with multiple copies that exhibit the highest protein expression level will be screened out through zeocinspread plates (Daly and Hearn, 2005). This zeocin selective marker for transformation selection is important regarding to the convenience of genetic manipulation in yeast. All the procedure typically takes about 10-15 days for a complete procedure from subcloning to protein expression. A potential disadvantage of the yeast culture concerns the difficulty in cell disruption due to the thick and hard cell walls.

\section{Insect cell}

The baculovirus infected insect cell system is undoubtedly the dominant heterologous expression system for obtaining eukaryotic IMPs (Contreras-Gomez et al., 2014). The most common method for generating recombinant baculovirus is based on the site-specific transposition of an expression cassette into a baculovirus shuttle vector (bacmid) that is amplified in E. coli (Ciccarone et al., 1998). The process is very convenient: clone the target gene into the pFastBac vector which uses the strong AcMNPV polyhedron $(\mathrm{PH})$ as the promoter for high level protein expression, then transform the pFastBac vector into DH10Bac E. coli competent cells. DH10Bac cells possess a baculovirus shuttle vector (bacmid) with a transposon site and a helper plasmid, thus can help the pFastBac vector to have a transposition on the bacmid. Once the transposition occurs and the recombinant bacmid is generated, the bacmid could be isolated and purified for transfection. After the insect cells are cultured into a desired confluence, they are transfected by the purified bacmid DNA to generate a recombinant baculovirus that used for preliminary expression test (Contreras-Gomez et al., 2014). The pFastBac is ampicillin resistance and Bacmid is kanamycin resistance, and these selective markers provide expedience for this baculovirus expression system. It takes approximately 3-4 weeks to complete these procedures for initial protein expression test.

There are two most popular insect cell lines used for IMP expression, Spodoptera frugiperda (Sf9) and Trichoplusia ni (Hi5). Heterologous proteins have disparate performances on the yield and behavior when expressed in these two cell 
lines (Unger and Peleg, 2012). Till now, 30 structures were obtained for eukaryotic IMPs from Sf9 expression system and 5 from $\mathrm{Hi} 5$ (Table 4).

After the protein IL-2 was first expressed in large scale with the baculovirus-infected insect cells in 1985, this system has been quickly accepted and widely used (Smith et al., 1983; Maeda et al., 1985). Owing to the convenience of scale up, safety and accuracy (Kost et al., 2005), the baculoviral insect cell system has yielded the largest number of eukaryotic IMPs up to date (Table 4). Notably, among the 35 eukaryotic IMP structures, 23 are of G-protein coupled receptors (GPCR) (Table 4). The insect cell system has been the prevailing expression system for eukaryotic IMP. However, the cost for the cultural medium may represent a serious roadblock for most laboratories.

\section{Mammalian cell}

Mammalian expression system has become one of the popular recombinant protein production systems for its proper post-translational modification and human protein-like structure assembly (Khan, 2013). HEK (human embryo kidney) and $\mathrm{CHO}$ (Chinese hamster ovary) are two broadly used cell lines for recombinant expression. These two cell lines are extensively applied by researchers to do functional assay such as the electrophysiological assay (Kawate et al., 2009). Both these two cell lines can be applied for transient and stable transfections (Zhu, 2012). For the transient transfection approach, it is relative easier to reach to a reasonable protein expression level, but this expression level may vary from batch to batch. On the other hand, although the proteins have higher productivity and less variation in the stable transfection method, it is very time consuming (one month at least) (Condreay et al., 1999; Baldwin et al., 2003). Consequently, it is a balance for scientists to choose between these two transfection methods.

HEK293 is a specific cell line originally derived from HEK cells, while the number "293" comes from Graham's habit of numbering his experiments (Louis et al., 1997). Large scale, transient transfection of HEK293 in suspension culture is a reliable way to generate milligram quantities of recombinant eukaryotic IMPs. When the gene of interest is ligated into the vector pcDNA3 or pCMV5, the complete plasmid is then transfected into the HEK293 cells and the cells are harvested after $48 \mathrm{~h}$ (Thomas and Smart, 2005). The whole procedure is more or less similar to that of the insect cell system, only with a couple of exceptions. For example, $5 \%-10 \% \mathrm{CO}_{2}$ is required for maintaining the HEK293 cells, and the culture temperature is $37^{\circ} \mathrm{C}$ for HEK293 but not $27^{\circ} \mathrm{C}$ as for insect cells. The overall process usually requires one to two weeks from initial cloning to small scale test for the transient expression. However, ascribe to the low yield, slow growth rate and higher cost of complex media (Sunley and Butler, 2010), the number of eukaryotic IMP structures generated based on the mammalian cells is very limited. So far, only three eukaryotic IMP structures are from this system, and two of them are obtained from HEK293 cells (Table 5).
The BacMam system has to be mentioned for its safety, reproducibility and efficiency (Dukkipati et al., 2008). The baculoviruses are engineered by inserting a mammalian expression cassette for delivering foreign genes in mammalian cells. Their non-replicating property makes they are safe and welltolerated by mammalian cells. BacMam system gains widespread use for its safety and rapid manipulation (Reeves et al., 2002; Baconguis and Gouaux, 2012). Depending on the cell type, cell division rate and transduction efficiency, it lasts 514 days to detect the gene expression (Dukkipati et al., 2008). The dopamine transporter structure was determined by the BacMam system (Penmatsa et al., 2013).

From the foregoing discussion, it is concluded that every expression system has their distinctive properties for protein expression. We compare their relative merits for an intuitional understanding of each system which can help researchers to make the best choice for their proteins expression (Table 6).

\section{HOMOLOGUE SCREEN}

Eukaryotic membrane proteins are very difficult to yield in large quantities, and most of them tend to be unstable in the presence of detergents. As a result, identification of wellexpressed proteins is very essential. Homologue screen is widely applied for researchers to discover well-behaved proteins (Kawate et al., 2009; Xiaowei Hou, 2012).

Fluorescence detected size exclusion chromatography (FSEC) is a powerful method for homologue screen (Drew et al., 2006; Newstead et al., 2007). Compared with the common protocols, GFP fusion membrane proteins can be detected by measuring fluorescence in whole cells during the overexpression process. It saves time to help people preclude proteins that have no expression or low expression level. Also, it is much easier to assess the integrity of proteins by detecting the fluorescence in SDS polyacrylamide gels. Moreover, FSEC could be employed to figure out the most stable detergents in initial detergent screen. Considering these benefits, this technology is very widely applied (Jasti et al., 2007; Gonzales et al., 2009; Kawate et al., 2009; Sobolevsky et al., 2009). Taking P2X receptor as an example (Kawate et al., 2009), because of its aggregation and instability problems, researchers applied this method to screen 35 orthologs and finally got one species which was fit for crystallization. FSEC is proven to be one of the most robust methods to facilitate the identification of appropriate candidates for solving the structures of eukaryotic membrane proteins.

\section{OPTIMAL CONSTRUCTS DESIGN}

Optimizing constructs is very beneficial for getting the wellpacked crystals. One way for optimizing constructs is to "cut off". Limited proteolysis is a conventional method to find the optimal constructs. Besides, it is worth noting that either $\mathrm{N}$-terminal tag or C-terminal tag is removed before crystallization in most crystallization cases (Long et al., 2005; Long 
A

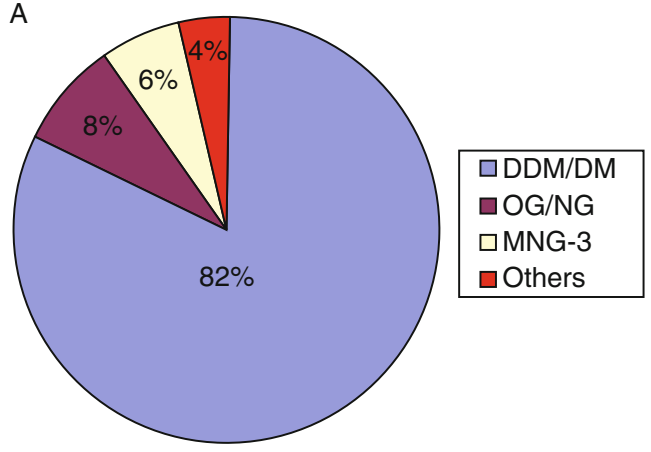

B

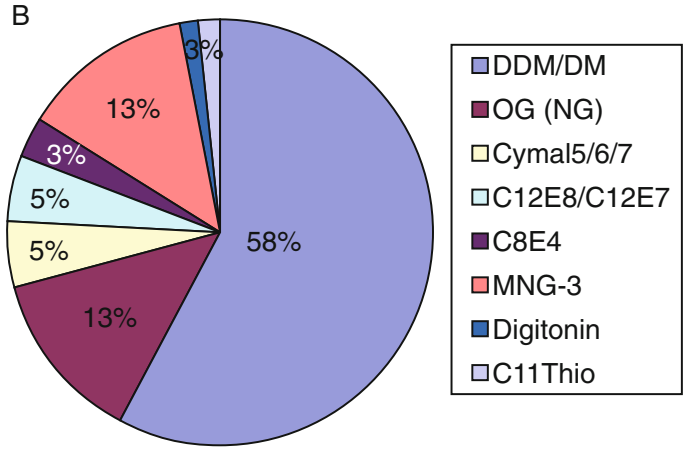

Figure 2. Detergents used for extraction and crystallization of eukaryotic membrane proteins. (A) Detergents for protein extraction and purification. DDM/DM can be applied for most eukaryotic membrane proteins in extraction step. (B) Detergents for protein crystallization. DDM/DM is the major detergent for the crystallization of eukaryotic membrane proteins.

et al., 2007; Gonzales et al., 2009; Maeda et al., 2009; Sobolevsky et al., 2009; Tao et al., 2009). For instance, the desensitized ASIC1 was crystallized by removal of 25 $\mathrm{N}$-terminal and 64 C-terminal residues (Jasti et al., 2007).

The contrary way for optimizing constructs is to "add up". T4 lysozyme (T4L) insertion and Fab/nanobody replacement are applied to produce stable proteins. The T4L fragment is soluble enough to effectively increase the solvent-exposed area, thereby facilitating protein-protein interactions and generating novel crystal packing interfaces (Cherezov et al., 2007). Fab/ nanobody, which are generated from monoclonal antibodies, can reduce the protein flexibility and improve the conformational homogeneity (Zhou et al., 2001; Rasmussen et al., 2007). GPCR is one of the most successful cases employing T4L and Fab/nanobody to the ultimate structure determination (Rasmussen et al., 2007; Rasmussen et al., 2011a, b).

Mutagenesis is an alternative way for constructs design. In order to improve the crystallization behavior and stabilize the tetrameric state of the glutamate receptor GluA2, point mutations were introduced, preventing non-specific aggregation and disulphide bond formation (Sobolevsky et al., 2009). And E329Q was introduced in order to stabilize GLUT1 in a certain conformation (Deng et al., 2014). Plus, glycosylation is the most common post-translational modification of eukaryotic membrane proteins and leads to heterogeneity of proteins. Thus, mutating of glycosylation sites or deglycosylation by enzymes is an essential step for crystallization (Deng et al., 2014).

\section{DETERGENTS, LIPIDS AND CRYSTALLIZATION}

We have summarized the detergents used for protein purification and crystallization from Table 1. 51 eukaryotic membrane proteins can be extracted from DDM or DM (Fig. 2A), suggesting DDM/DM are the detergents suitable for the extraction process of the majority of eukaryotic membrane proteins. Collaterally, nearly half of the eukaryotic membrane protein crystals are obtained from DDM/DM, indicating DDM/DM are worthy of a trial for crystallization in the first place (Fig. 2B and Table 1). Apart from these conventionally applied detergents, new detergents have also been developed to meet the new requirements. For example, when purifying $\beta_{2}$ adrenergic receptor-Gs protein, the authors stabilized protein complex by exchanging DDM with a newly developed maltose neopentyl glycol detergent MNG-3 (NG310, Anatrace) to prevent the complex dissociated from original detergent DDM (Chae et al., 2010; Rasmussen et al., 2011a, b).

It is worth noting that additional lipids are able to help crystal packing. There are three ways of lipid combinations. The first is mixing lipids with detergent(s) in hanging or sitting drop during crystallization. Take mammalian voltagedependent shaker family potassium channel as an example, the author utilized $0.1 \mathrm{mg} / \mathrm{mL}$ 3:1:1 POPC: POPE: POPG throughout purification and crystallization to obtain crystals (Long et al., 2005). The second approach is lipid cubic phase (LCP) method. The lipid cubic phase is a dynamic structure consisting of a highly organized single lipid bilayer pervaded by an inter-connected aqueous channel (Landau and Rosenbusch, 1996). Martin has an elaborate discussion about LCP method which we will not go into details in this review (Caffrey and Cherezov, 2009). The crystal structure of $\beta_{2} A R-$ GS complex was determined by the use of 7.7 MAG as the host lipid for crystallization (Rasmussen et al., 2011a, b). The third way is bicelle method, which is regarded as an intermediate approach between the traditional detergent crystallization method and the rigid LCP method. Bicelle can be considered as a lipid bilayer disc that formed by a long chain lipid and a short chain lipid or detergent (Agah and Faham, 2012). The general composition is 3:1 DMPC: CHAPSO. Several protein structures were determined utilizing bicelle method (Rasmussen et al., 2007; Payandeh et al., 2011).

Last but not the least, we will elaborate a few messages for the crystallization of eukaryotic membrane protein drawn from Table 1: (a) Protein concentration: almost all the protein concentration for crystallization is above $5 \mathrm{mg} / \mathrm{mL}$. (b) Crystallization temperature: if we expel the LCP method that is routinely crystallized at $20 \pm 2^{\circ} \mathrm{C}$, nearly half of the eukaryotic membrane 
proteins are crystallized at low temperature, especially on $4^{\circ} \mathrm{C}$. At cold temperature, for protein with "normal" solubility, protein will be more soluble in high salt and precipitate from lower concentration of the precipitant reagents, and also the equilibrium diffusion rate occurs more slowly. These manifest that crystallization at lower temperature is absolutely an indispensable trial. (c) Crystallization methods: hanging drop or sitting drop crystallization method is the main and conventional approach for most eukaryotic membrane protein. LCP method is an up-rising star which is extensively applied in determining the GPCR's structures which we have mentioned before. Remarkably, LCP method is not only propitious to GPCR, but also is able to be applied for none-GPCR protein structures determination (Suzuki et al., 2014).

\section{CONCLUSION}

In this review, we discuss the benefits and drawbacks of different expression systems for eukaryotic membrane protein, and illustrate some general methods of recent advances for eukaryotic membrane protein purification and crystallization. We hope our work can provide help to those who are interested and work on eukaryotic membrane proteins. Although the discussion of eukaryotic membrane protein structure determined by Cryo-EM or NMR is beyond the scope of this review, the general methodologies and technical strategies summarized here also come to an aid in protein yield augment and sample homogeneity improvement for Cryo-EM and NMR. They are very powerful tools to solve structures, for instance, the Cryo-EM was applied to determine TrpV1 structures (Cao et al., 2013; Liao et al., 2013). With the development of advanced technologies, more and more eukaryotic membrane protein structures will emerge to answer the most significant questions in life sciences and provide the novel pharmaceutical targets in drug design.

\section{ACKNOWLEDGEMENTS}

We apologize to colleagues whose work could not be cited due to the scope of this review. We would like to thank members in Yan laboratory for discussions. We thank Brendan Lehnert, Xinlei Sheng, Quanxiu Li, Dan Ma and Xinhui Zhou for critical reading. This work was supported by funds from the National Basic Research Program (973 Program) (No. 2011CB910501), the National Natural Science Foundation of China (Grant Nos. 31321062-20131319400, 31125009, and 91017011), and funds from Tsinghua-Peking Center for Life Sciences. The research of N.Y. was supported in part by an International Early Career Scientist grant from the Howard Hughes Medical Institute.

\section{ABBREVIATIONS}

$\beta_{2} A R$, human $\beta 2$ adrenergic G-protein-coupled receptor; $A B C B 10$, ATP-binding cassette (ABC) transporters; AHA2, Arabidopsis thaliana auto-inhibited H1-ATPase 2; ASIC1, acid-sensing ion channel 1; CAAX protease Ste24p, $\mathrm{C}$ is cysteine redidue, $\mathrm{A}$ is an aliphatic residue and $X$ is any residue. It is a zinc metalloprotease catalyzing two proteolytic steps in the maturation of yeast mating pheromone a-factor; $\mathrm{C}_{8} \mathrm{E}_{4}$, tetraethyleneglycol monooctyl ether; $\mathrm{C}_{12} \mathrm{E}_{7}$, dodecylheptaglycol; $\mathrm{C}_{12} \mathrm{E}_{8}$, polyoxyethylene dodecyl ether; $\mathrm{CHS}$, cholesteryl hemisuccinate; $\mathrm{CmClC}$, cyanidioschyzon merolae chloride $\left(\mathrm{Cl}^{-}\right)$ions transporter; $\quad C_{11}$ Thio, $n$-undecyl- $\beta$-Dthiomaltopyranoside; CXCR4, human chemokine receptors; CX26, connexin 26 gap junction; CYMAL5, 5-cyclohexyl-1-pentyl- $\beta-D-$ maltoside; CYMAL6, 6-cyclohexyl-1-hexyl- $\beta$-D-maltoside; CYMAL7, 7-cyclohexyl-1-heptyl- $\beta$-D-maltoside; $\quad$ DDM, $\quad n$-dodecyl- $\beta$-Dmaltoside; DM, n-decyl- $\beta$-D-maltoside; FLAP, 5-lipoxygenaseactivating protein; GIRK2 (Kir3.2), $\mathrm{K}^{+}$channel: $\mathrm{G}$ protein-gated $\mathrm{K}+$ channels; GluA2, a-amino-3-hydroxy-5-methyl-4-isoxazole propionic acid (AMPA)-sensitive ionotropic glutamate receptor; GLuCla, caenorhabditis elegans glutamate-gated chloride channel a (GluCl), an inhibitory anion-selective Cys-loop receptor; HsAQP4, human aquaporin 4; HsAQP5, human aquaporin 5; Human BK channel, high-conductance voltage- and Ca21-activated $\mathrm{K} 1$ channels; K2P1, two-pore domain potassium $(\mathrm{K}+)$ channels; $\mathrm{K} v 1.2$, voltage-dependent shaker family potassium channel; Kv1.2Kv2.1 paddle, 'paddle-chimaera channel', voltage-sensor paddle has been transferred from Kv2.1 to Kv1.2; LTC4S, cysteinyl leukotrienes; M-Ppase, membrane-integral pyrophosphatases; MAPEG, membrane-associated proteins in eicosanoid and glutathione metabolism; MNG, maltose-neopentyl glycol; NG, n-nonyl- $\beta$-D-glucopyranoside; NM, n-nonyl- $\beta$-D-maltoside; N/OFQ receptor, nociceptin/orphanin FQ receptor; OG, n-octyl- $\beta$-Dglucoside; OGNG, octyl glucose neopentyl glycol; $\mathrm{P} 2 \mathrm{X}_{4}$, cationselective ion channels gated by extracellular ATP; PAR1, proteaseactivated receptor 1; PfAQP, Plasmodium falciparum aquaglyceroporin; PiPT, a Fungal (Piriformospora indica) highaffinity phosphate transporter; POPC, 1-palmitoyl-2-oleoyl-snglycero-3-phosphocholine; POPE, 1-palmitoyl-2-oleoyl-sn-glycero3-phosphoethanolamine; POPG, 1-palmitoyl-2-oleoyl-sn-glycero-3phosphoglycero; RhCG, rhesus C glycoprotein; SoPIP2, 1, spinach plant plasma membrane aquaporin; TRAAK, TWIK-related arachidonic acid-stimulated $\mathrm{K}^{+}$channel; UDTM, n-undecyl- $\beta$ maltoside; UT-B, urea transporters- $\mathrm{B}$; $\mathrm{VrH}^{+}$-Ppase, vigna radiate H1-translocating pyrophosphatases; ZMPSTE24, zinc metallopeptidase STE24.

\section{COMPLIANCE WITH ETHICS GUIDELINES}

Yuan He, Kan Wang, and Nieng Yan declare that we have no conflict of interest.

This review does not contain any studies with human or animal subjects performed by the any of the authors.

\section{OPEN ACCESS}

This article is distributed under the terms of the Creative Commons Attribution License which permits any use, distribution, and reproduction in any medium, provided the original author(s) and the source are credited.

\section{REFERENCES}

Abrahams JP, Leslie AG, Lutter R, Walker JE (1994) Structure at 2.8 A resolution of F1-ATPase from bovine heart mitochondria. Nature 370:621-628 
AegeanSoftware (2005) NoteExpress, 2.0 edn. (NoteExpress is a perfect assistant and information manager for researchers, scholars, students, and librarians. NoteExpress is designed to help you organize research notes and bibliographic references, generate bibliographies automatically, search and capture bibliographic data from Internet with efficiency and ease. NoteExpress is well integrated with Microsoft Word. It can format bibliographies in many popular styles)

Agah S, Faham S (2012) Crystallization of membrane proteins in bicelles. Methods Mol Biol 914:3-16

Ago H, Kanaoka Y, Irikura D, Lam BK, Shimamura T, Austen KF, Miyano M (2007) Crystal structure of a human membrane protein involved in cysteinyl leukotriene biosynthesis. Nature 448:609-612

Aisenbrey C, Borowik T, Bystrom R, Bokvist M, Lindstrom F, Misiak $\mathrm{H}$, Sani MA, Grobner G (2008) How is protein aggregation in amyloidogenic diseases modulated by biological membranes? Eur Biophys J 37:247-255

Aller SG, Yu J, Ward A, Weng Y, Chittaboina S, Zhuo R, Harrell PM, Trinh YT, Zhang Q, Urbatsch IL et al (2009) Structure of P-glycoprotein reveals a molecular basis for poly-specific drug binding. Science 323:1718-1722

Amunts A, Drory O, Nelson N (2007) The structure of a plant photosystem I supercomplex at 3.4. A resolution. Nature 447:58-63

Baconguis I, Gouaux E (2012) Structural plasticity and dynamic selectivity of acid-sensing ion channel-spider toxin complexes. Nature 489:400-405

Baldwin SL, Powell TD, Wonderling RS, Keiser KC, Morales T, Hunter S, McDermott M, Radecki SV, Milhausen MJ (2003) Transient and stable transfection of Chinese hamster ovary cells with the recombinant feline erythropoietin gene and expression, purification, and biological activity of feline erythropoietin protein. Am J Vet Res 64:1465-1471

Bernaudat F, Frelet-Barrand A, Pochon N, Dementin S, Hivin P, Boutigny S, Rioux JB, Salvi D, Seigneurin-Berny D, Richaud P et al (2011) Heterologous expression of membrane proteins: choosing the appropriate host. PLoS One 6:e29191

Bill RM, Henderson PJ, Iwata S, Kunji ER, Michel H, Neutze R, Newstead S, Poolman B, Tate CG, Vogel H (2011) Overcoming barriers to membrane protein structure determination. Nat Biotechnol 29:335-340

Bkaily G, Al-Khoury J, Jacques D (2014) Nuclear membranes GPCRs: implication in cardiovascular health and diseases. Curr Vasc Pharmacol 12(2):215-222

Bornert O, Alkhalfioui F, Logez C, Wagner R (2012) Overexpression of membrane proteins using Pichia pastoris. Curr Protoc Protein Sci Chapter 29:22-29

Brohawn SG, Del MJ, MacKinnon R (2012) Crystal structure of the human K2P TRAAK, a lipid- and mechano-sensitive $\mathrm{K}+$ ion channel. Science 335:436-441

Burgess-Brown NA, Sharma S, Sobott F, Loenarz C, Oppermann U, Gileadi O (2008) Codon optimization can improve expression of human genes in Escherichia coli: a multi-gene study. Protein Exp Purif 59:94-102

Caffrey M, Cherezov V (2009) Crystallizing membrane proteins using lipidic mesophases. Nat Protoc 4:706-731
Cao E, Liao M, Cheng Y, Julius D (2013) TRPV1 structures in distinct conformations reveal activation mechanisms. Nature 504:113-118

Cereghino JL, Cregg JM (2000) Heterologous protein expression in the methylotrophic yeast Pichia pastoris. Fems Microbiol Rev 24:45-66

Chae PS, Rasmussen SG, Rana RR, Gotfryd K, Chandra R, Goren MA, Kruse AC, Nurva S, Loland CJ, Pierre Y et al (2010) Maltoseneopentyl glycol (MNG) amphiphiles for solubilization, stabilization and crystallization of membrane proteins. Nat Methods 7:1003-1008

Cherezov V, Rosenbaum DM, Hanson MA, Rasmussen SG, Thian FS, Kobilka TS, Choi HJ, Kuhn P, Weis WI, Kobilka BK et al (2007) High-resolution crystal structure of an engineered human beta2adrenergic $G$ protein-coupled receptor. Science 318:1258-1265

Chien EY, Liu W, Zhao Q, Katritch V, Han GW, Hanson MA, Shi L, Newman AH, Javitch JA, Cherezov V et al (2010) Structure of the human dopamine D3 receptor in complex with a D2/D3 selective antagonist. Science 330:1091-1095

Ciccarone VC, Polayes DA, Luckow VA (1998) Generation of recombinant baculovirus DNA in $E$. coli using a baculovirus shuttle vector. Methods Mol Med 13:213-235

Condreay JP, Witherspoon SM, Clay WC, Kost TA (1999) Transient and stable gene expression in mammalian cells transduced with a recombinant baculovirus vector. Proc Natl Acad Sci USA 96:127-132

Contreras-Gomez A, Sanchez-Miron A, Garcia-Camacho F, MolinaGrima E, Chisti Y (2014) Protein production using the baculovirus-insect cell expression system. Biotechnol Prog 30:1-18

Daly R, Hearn MT (2005) Expression of heterologous proteins in Pichia pastoris: a useful experimental tool in protein engineering and production. J Mol Recognit 18:119-138

Deng D, Xu C, Sun P, Wu J, Yan C, Hu M, Yan N (2014) Crystal structure of the human glucose transporter GLUT1. Nature 510:121-125

Drew D, Lerch M, Kunji E, Slotboom DJ, de Gier JW (2006) Optimization of membrane protein overexpression and purification using GFP fusions. Nat Methods 3:303-313

Dukkipati A, Park HH, Waghray D, Fischer S, Garcia KC (2008) BacMam system for high-level expression of recombinant soluble and membrane glycoproteins for structural studies. Protein Exp Purif 62:160-170

Dumon-Seignovert L, Cariot G, Vuillard L (2004) The toxicity of recombinant proteins in Escherichia coli: a comparison of overexpression in BL21(DE3), C41(DE3), and C43(DE3). Protein Expr Purif 37:203-206

Feng L, Campbell EB, Hsiung Y, MacKinnon R (2010) Structure of a eukaryotic CLC transporter defines an intermediate state in the transport cycle. Science 330:635-641

Ferguson AD, McKeever BM, Xu S, Wisniewski D, Miller DK, Yamin TT, Spencer RH, Chu L, Ujjainwalla F, Cunningham BR et al (2007) Crystal structure of inhibitor-bound human 5-lipoxygenase-activating protein. Science 317:510-512

Gonzales EB, Kawate T, Gouaux E (2009) Pore architecture and ion sites in acid-sensing ion channels and $\mathrm{P} 2 \mathrm{X}$ receptors. Nature 460:599-604 
Granier S, Manglik A, Kruse AC, Kobilka TS, Thian FS, Weis WI, Kobilka BK (2012) Structure of the delta-opioid receptor bound to naltrindole. Nature 485:400-404

Gruswitz F, Chaudhary S, Ho JD, Schlessinger A, Pezeshki B, Ho CM, Sali A, Westhoff CM, Stroud RM (2010) Function of human Rh based on structure of RhCG at 2.1 A. Proc Natl Acad Sci USA 107:9638-9643

Haga K, Kruse AC, Asada H, Yurugi-Kobayashi T, Shiroishi M, Zhang C, Weis WI, Okada T, Kobilka BK, Haga T et al (2012) Structure of the human M2 muscarinic acetylcholine receptor bound to an antagonist. Nature 482:547-551

Hanson MA, Roth CB, Jo E, Griffith MT, Scott FL, Reinhart G, Desale H, Clemons B, Cahalan SM, Schuerer SC et al (2012) Crystal structure of a lipid $\mathrm{G}$ protein-coupled receptor. Science 335:851-855

Hattori M, Gouaux E (2012) Molecular mechanism of ATP binding and ion channel activation in P2X receptors. Nature 485:207-212

Hibbs RE, Gouaux E (2011) Principles of activation and permeation in an anion-selective Cys-loop receptor. Nature 474:54-60

Ho JD, Yeh R, Sandstrom A, Chorny I, Harries WE, Robbins RA, Miercke LJ, Stroud RM (2009) Crystal structure of human aquaporin 4 at 1.8. A and its mechanism of conductance. Proc Natl Acad Sci USA 106:7437-7442

Hollenstein K, Kean J, Bortolato A, Cheng RK, Dore AS, Jazayeri A, Cooke RM, Weir M, Marshall FH (2013) Structure of class B GPCR corticotropin-releasing factor receptor 1. Nature 499:438-443

Horsefield R, Norden K, Fellert M, Backmark A, Tornroth-Horsefield S, Terwisscha VSA, Kvassman J, Kjellbom P, Johanson U, Neutze R (2008) High-resolution x-ray structure of human aquaporin 5. Proc Natl Acad Sci USA 105:13327-13332

Ishikawa $\mathrm{Y}$, Inoue N, Zhenfang Y, Nakae Y (2004) Molecular mechanisms and drug development in aquaporin water channel diseases: the translocation of aquaporin- 5 from lipid rafts to the apical plasma membranes of parotid glands of normal rats and the impairment of it in diabetic or aged rats. $\mathrm{J}$ Pharmacol Sci 96:271-275

Jaakola VP, Griffith MT, Hanson MA, Cherezov V, Chien EY, Lane JR, ljzerman AP, Stevens RC (2008) The 2.6 angstrom crystal structure of a human $\mathrm{A} 2 \mathrm{~A}$ adenosine receptor bound to an antagonist. Science 322:1211-1217

Jasti J, Furukawa H, Gonzales EB, Gouaux E (2007) Structure of acid-sensing ion channel 1 at 1.9. A resolution and low $\mathrm{pH}$. Nature 449:316-323

Jin MS, Oldham ML, Zhang Q, Chen J (2012) Crystal structure of the multidrug transporter P-glycoprotein from Caenorhabditis elegans. Nature 490:566-569

Kawate T, Michel JC, Birdsong WT, Gouaux E (2009) Crystal structure of the ATP-gated P2X(4) ion channel in the closed state. Nature 460:592-598

Khan KH (2013) Gene expression in mammalian cells and its applications. Adv Pharm Bull 3:257-263

Kost TA, Condreay JP, Jarvis DL (2005) Baculovirus as versatile vectors for protein expression in insect and mammalian cells. Nat Biotechnol 23:567-575

Krogh A, Larsson B, von Heijne G, Sonnhammer EL (2001) Predicting transmembrane protein topology with a hidden Markov model: application to complete genomes. J Mol Biol 305:567-580
Kruse AC, Hu J, Pan AC, Arlow DH, Rosenbaum DM, Rosemond E, Green HF, Liu T, Chae PS, Dror RO et al (2012) Structure and dynamics of the M3 muscarinic acetylcholine receptor. Nature 482:552-556

Kurisu G, Zhang H, Smith JL, Cramer WA (2003) Structure of the cytochrome b6f complex of oxygenic photosynthesis: tuning the cavity. Science 302:1009-1014

Landau EM, Rosenbusch JP (1996) Lipidic cubic phases: a novel concept for the crystallization of membrane proteins. Proc Natl Acad Sci USA 93:14532-14535

Levin EJ, Cao Y, Enkavi G, Quick M, Pan Y, Tajkhorshid E, Zhou M (2012) Structure and permeation mechanism of a mammalian urea transporter. Proc Natl Acad Sci USA 109:11194-11199

Li P, Anumanthan A, Gao XG, llangovan K, Suzara VV, Duzgunes N, Renugopalakrishnan V (2007) Expression of recombinant proteins in Pichia pastoris. Appl Biochem Biotechnol 142:105-124

Liao M, Cao E, Julius D, Cheng Y (2013) Structure of the TRPV1 ion channel determined by electron cryo-microscopy. Nature 504:107-112

Lin SM, Tsai JY, Hsiao CD, Huang YT, Chiu CL, Liu MH, Tung JY, Liu TH, Pan RL, Sun YJ (2012) Crystal structure of a membraneembedded H+-translocating pyrophosphatase. Nature 484:399403

Liu Z, Yan H, Wang K, Kuang T, Zhang J, Gui L, An X, Chang W (2004) Crystal structure of spinach major light-harvesting complex at 2.72. A resolution. Nature 428:287-292

Long SB, Campbell EB, Mackinnon R (2005) Crystal structure of a mammalian voltage-dependent Shaker family $\mathrm{K}+$ channel. Science 309:897-903

Long SB, Tao X, Campbell EB, MacKinnon R (2007) Atomic structure of a voltage-dependent $\mathrm{K}+$ channel in a lipid membrane-like environment. Nature 450:376-382

Louis N, Evelegh C, Graham FL (1997) Cloning and sequencing of the cellular-viral junctions from the human adenovirus type 5 transformed 293 cell line. Virology 233:423-429

Lu P, Ma D, Yan C, Gong X, Du M, Shi Y (2014) Structure and mechanism of a eukaryotic transmembrane ascorbate-dependent oxidoreductase. Proc Natl Acad Sci USA 111(5):1813-1818

Macauley-Patrick S, Fazenda ML, McNeil B, Harvey LM (2005) Heterologous protein production using the Pichia pastoris expression system. Yeast 22:249-270

Maeda S, Kawai T, Obinata M, Fujiwara H, Horiuchi T, Saeki Y, Sato Y, Furusawa M (1985) Production of human alpha-interferon in silkworm using a baculovirus vector. Nature 315:592-594

Maeda S, Nakagawa S, Suga M, Yamashita E, Oshima A, Fujiyoshi Y, Tsukihara T (2009) Structure of the connexin 26 gap junction channel at 3.5. A resolution. Nature 458:597-602

Manglik A, Kruse AC, Kobilka TS, Thian FS, Mathiesen JM, Sunahara RK, Pardo L, Weis WI, Kobilka BK, Granier S (2012) Crystal structure of the micro-opioid receptor bound to a morphinan antagonist. Nature 485:321-326

Mijakovic I, Petranovic D, Macek B, Cepo T, Mann M, Davies J, Jensen PR, Vujaklija D (2006) Bacterial single-stranded DNAbinding proteins are phosphorylated on tyrosine. Nucleic Acids Res 34:1588-1596

Miller AN, Long SB (2012) Crystal structure of the human two-pore domain potassium channel K2P1. Science 335:432-436 
Mironova R, Niwa T, Handzhiyski Y, Sredovska A, Ivanov I (2005) Evidence for non-enzymatic glycosylation of Escherichia coli chromosomal DNA. Mol Microbiol 55:1801-1811

Miroux B, Walker JE (1996) Over-production of proteins in Escherichia coli: mutant hosts that allow synthesis of some membrane proteins and globular proteins at high levels. J Mol Biol 260:289-298

Murray CW, Verdonk ML, Rees DC (2012) Experiences in fragmentbased drug discovery. Trends Pharmacol Sci 33:224-232

Neophytou I, Harvey R, Lawrence J, Marsh P, Panaretou B, Barlow D (2007) Eukaryotic integral membrane protein expression utilizing the Escherichia coli glycerol-conducting channel protein (GlpF). Appl Microbiol Biotechnol 77:375-381

Newby ZE, O'Connell JR, Robles-Colmenares Y, Khademi S, Miercke LJ, Stroud RM (2008) Crystal structure of the aquaglyceroporin PfAQP from the malarial parasite Plasmodium falciparum. Nat Struct Mol Biol 15:619-625

Newstead S, Kim H, von Heijne G, Iwata S, Drew D (2007) Highthroughput fluorescent-based optimization of eukaryotic membrane protein overexpression and purification in Saccharomyces cerevisiae. Proc Natl Acad Sci USA 104:13936-13941

Nishida M, Cadene M, Chait BT, MacKinnon R (2007) Crystal structure of a Kir3.1-prokaryotic Kir channel chimera. Embo J 26:4005-4015

Overington JP, Al-Lazikani B, Hopkins AL (2006) How many drug targets are there? Nat Rev Drug Discov 5:993-996

Parker JL, Newstead S (2014) Molecular basis of nitrate uptake by the plant nitrate transporter NRT1.1. Nature 507:68-72

Payandeh J, Scheuer T, Zheng N, Catterall WA (2011) The crystal structure of a voltage-gated sodium channel. Nature 475:353-358

Pedersen BP, Buch-Pedersen MJ, Morth JP, Palmgren MG, Nissen $P(2007)$ Crystal structure of the plasma membrane proton pump. Nature 450:1111-1114

Pedersen BP, Kumar H, Waight AB, Risenmay AJ, Roe-Zurz Z, Chau $\mathrm{BH}$, Schlessinger A, Bonomi M, Harries $W$, Sali $A$ et al (2013) Crystal structure of a eukaryotic phosphate transporter. Nature 496:533-536

Penmatsa A, Wang KH, Gouaux E (2013) X-ray structure of dopamine transporter elucidates antidepressant mechanism. Nature 503:85-90

Phillips R, Ursell T, Wiggins P, Sens P (2009) Emerging roles for lipids in shaping membrane-protein function. Nature 459:379-385

Pryor EJ, Horanyi PS, Clark KM, Fedoriw N, Connelly SM, KoszelakRosenblum M, Zhu G, Malkowski MG, Wiener MC, Dumont ME (2013) Structure of the integral membrane protein CAAX protease Ste24p. Science 339:1600-1604

Quigley A, Dong YY, Pike AC, Dong L, Shrestha L, Berridge G, Stansfeld PJ, Sansom MS, Edwards AM, Bountra C et al (2013) The structural basis of ZMPSTE24-dependent laminopathies. Science 339:1604-1607

Rasmussen SG, Choi HJ, Rosenbaum DM, Kobilka TS, Thian FS, Edwards PC, Burghammer M, Ratnala VR, Sanishvili R, Fischetti RF et al (2007) Crystal structure of the human beta2 adrenergic G-protein-coupled receptor. Nature 450:383-387

Rasmussen SG, Choi HJ, Fung JJ, Pardon E, Casarosa P, Chae PS, Devree BT, Rosenbaum DM, Thian FS, Kobilka TS et al (2011a) Structure of a nanobody-stabilized active state of the beta(2) adrenoceptor. Nature 469:175-180
Rasmussen SG, DeVree BT, Zou Y, Kruse AC, Chung KY, Kobilka TS, Thian FS, Chae PS, Pardon E, Calinski D et al (2011b) Crystal structure of the beta2 adrenergic receptor-Gs protein complex. Nature 477:549-555

Reeves PJ, Callewaert N, Contreras R, Khorana HG (2002) Structure and function in rhodopsin: high-level expression of rhodopsin with restricted and homogeneous $\mathrm{N}$-glycosylation by a tetracycline-inducible $\mathrm{N}$-acetylglucosaminyltransferase I-negative HEK293S stable mammalian cell line. Proc Natl Acad Sci USA 99:13419-13424

Rosenbaum DM, Zhang C, Lyons JA, Holl R, Aragao D, Arlow DH, Rasmussen SG, Choi HJ, Devree BT, Sunahara RK et al (2011) Structure and function of an irreversible agonist-beta(2) adrenoceptor complex. Nature 469:236-240

Russell RB, Eggleston DS (2000) New roles for structure in biology and drug discovery. Nat Struct Biol 7(Suppl):928-930

Sahdev S, Khattar SK, Saini KS (2008) Production of active eukaryotic proteins through bacterial expression systems: a review of the existing biotechnology strategies. Mol Cell Biochem 307:249-264

Sanders CR, Myers JK (2004) Disease-related misassembly of membrane proteins. Annu Rev Biophys Biomol Struct 33:25-51

Shimamura T, Shiroishi M, Weyand S, Tsujimoto H, Winter G, Katritch V, Abagyan R, Cherezov V, Liu W, Han GW et al (2011) Structure of the human histamine $\mathrm{H} 1$ receptor complex with doxepin. Nature 475:65-70

Shintre CA, Pike AC, Li Q, Kim JI, Barr AJ, Goubin S, Shrestha L, Yang J, Berridge G, Ross J et al (2013) Structures of ABCB10, a human ATP-binding cassette transporter in apo- and nucleotidebound states. Proc Natl Acad Sci USA 110:9710-9715

Siu FY, He M, de Graaf C, Han GW, Yang D, Zhang Z, Zhou C, Xu Q, Wacker D, Joseph JS et al (2013) Structure of the human glucagon class B G-protein-coupled receptor. Nature 499:444-449

Smith GE, Summers MD, Fraser MJ (1983) Production of human beta interferon in insect cells infected with a baculovirus expression vector. Mol Cell Biol 3:2156-2165

Snider C, Stephen, HW (2014) Membrane proteins of known 3D structure. http://blanco.biomol.uci.edu/mpstruc/

Sobolevsky AI, Rosconi MP, Gouaux E (2009) X-ray structure, symmetry and mechanism of an AMPA-subtype glutamate receptor. Nature 462:745-756

Standfuss J, Xie G, Edwards PC, Burghammer M, Oprian DD, Schertler GF (2007) Crystal structure of a thermally stable rhodopsin mutant. J Mol Biol 372:1179-1188

Strausberg RL, Strausberg SL (2001) Overview of protein expression in saccharomyces cerevisiae. Curr Protoc Protein Sci Chapter 5:t5-t6

Sun F, Huo X, Zhai Y, Wang A, Xu J, Su D, Bartlam M, Rao Z (2005) Crystal structure of mitochondrial respiratory membrane protein complex II. Cell 121:1043-1057

Sun J, Bankston JR, Payandeh J, Hinds TR, Zagotta WN, Zheng N (2014) Crystal structure of the plant dual-affinity nitrate transporter NRT1.1. Nature 507:73-77

Sunley K, Butler M (2010) Strategies for the enhancement of recombinant protein production from mammalian cells by growth arrest. Biotechnol Adv 28:385-394

Suzuki H, Nishizawa T, Tani K, Yamazaki Y, Tamura A, Ishitani R, Dohmae N, Tsukita S, Nureki O, Fujiyoshi Y (2014) Crystal 
structure of a claudin provides insight into the architecture of tight junctions. Science 344:304-307

Tan Q, Zhu Y, Li J, Chen Z, Han GW, Kufareva I, Li T, Ma L, Fenalti G, Li J et al (2013) Structure of the CCR5 chemokine receptorHIV entry inhibitor maraviroc complex. Science 341:1387-1390

Tao X, Avalos JL, Chen J, MacKinnon R (2009) Crystal structure of the eukaryotic strong inward-rectifier $\mathrm{K}+$ channel Kir2.2 at $3.1 \mathrm{~A}$ resolution. Science 326:1668-1674

Tao X, Lee A, Limapichat W, Dougherty DA, MacKinnon R (2010) A gating charge transfer center in voltage sensors. Science 328:67-73

Thomas P, Smart TG (2005) HEK293 cell line: a vehicle for the expression of recombinant proteins. J Pharmacol Toxicol Methods 51:187-200

Thompson AA, Liu W, Chun E, Katritch V, Wu H, Vardy E, Huang XP, Trapella C, Guerrini R, Calo G et al (2012) Structure of the nociceptin/orphanin FQ receptor in complex with a peptide mimetic. Nature 485:395-399

Tornroth-Horsefield S, Wang Y, Hedfalk K, Johanson U, Karlsson M, Tajkhorshid E, Neutze R, Kjellbom P (2006) Structural mechanism of plant aquaporin gating. Nature 439:688-694

Tsukihara T, Aoyama H, Yamashita E, Tomizaki T, Yamaguchi $\mathrm{H}$, Shinzawa-Itoh K, Nakashima R, Yaono R, Yoshikawa S (1996) The whole structure of the 13-subunit oxidized cytochrome $\mathrm{C}$ oxidase at $2.8 \mathrm{~A}$. Science 272:1136-1144

Unger T, Peleg $Y$ (2012) Recombinant protein expression in the baculovirus-infected insect cell system. Methods Mol Biol 800:187-199

van Meer G, Voelker DR, Feigenson GW (2008) Membrane lipids: where they are and how they behave. Nat Rev Mol Cell Biol 9:112-124

Wacker D, Wang C, Katritch V, Han GW, Huang XP, Vardy E, McCorvy JD, Jiang Y, Chu M, Siu FY et al (2013) Structural features for functional selectivity at serotonin receptors. Science 340:615-619

Wang C, Jiang Y, Ma J, Wu H, Wacker D, Katritch V, Han GW, Liu W, Huang XP, Vardy E et al (2013a) Structural basis for molecular recognition at serotonin receptors. Science 340:610-614

Wang C, Wu H, Katritch V, Han GW, Huang XP, Liu W, Siu FY, Roth BL, Cherezov V, Stevens RC (2013b) Structure of the human smoothened receptor bound to an antitumour agent. Nature 497:338-343

Warne T, Serrano-Vega MJ, Baker JG, Moukhametzianov R, Edwards PC, Henderson R, Leslie AG, Tate CG, Schertler GF
(2008) Structure of a beta1-adrenergic G-protein-coupled receptor. Nature 454:486-491

White JF, Noinaj N, Shibata Y, Love J, Kloss B, Xu F, GvozdenovicJeremic J, Shah P, Shiloach J, Tate CG et al (2012) Structure of the agonist-bound neurotensin receptor. Nature 490:508-513

Whorton MR, MacKinnon R (2011) Crystal structure of the mammalian GIRK2 K+ channel and gating regulation by G proteins, PIP2, and sodium. Cell 147:199-208

Wu B, Chien EY, Mol CD, Fenalti G, Liu W, Katritch V, Abagyan R, Brooun A, Wells P, Bi FC et al (2010) Structures of the CXCR4 chemokine GPCR with small-molecule and cyclic peptide antagonists. Science 330:1066-1071

Wu H, Wacker D, Mileni M, Katritch V, Han GW, Vardy E, Liu W, Thompson AA, Huang XP, Carroll Fl et al (2012) Structure of the human kappa-opioid receptor in complex with JDTic. Nature 485:327-332

Wu H, Wang C, Gregory KJ, Han GW, Cho HP, Xia Y, Niswender CM, Katritch V, Meiler J, Cherezov V et al (2014) Structure of a class C GPCR metabotropic glutamate receptor 1 bound to an allosteric modulator. Science 344:58-64

Xia D, Yu CA, Kim H, Xia JZ, Kachurin AM, Zhang L, Yu L, Deisenhofer J (1997) Crystal structure of the cytochrome bc1 complex from bovine heart mitochondria. Science 277:60-66

Hou X, Pedi L, Diver MM, Long SB (2012) Crystal structure of the calcium release-activated calcium channel orai. Science 338 (6112):1308-1313

Yang Y, Hu Z, Liu Z, Wang Y, Chen X, Chen G (2009) High human GLUT1, GLUT2, and GLUT3 expression in Schizosaccharomyces pombe. Biochemistry (Mosc) 74:75-80

Yildirim MA, Goh KI, Cusick ME, Barabasi AL, Vidal M (2007) Drugtarget network. Nat Biotechnol. 25:1119-1126

Yurimoto H, Sakai Y (2009) Methanol-inducible gene expression and heterologous protein production in the methylotrophic yeast Candida boidinii. Biotechnol Appl Biochem 53:85-92

Zhang C, Srinivasan Y, Arlow DH, Fung JJ, Palmer D, Zheng Y, Green HF, Pandey A, Dror RO, Shaw DE et al (2012) Highresolution crystal structure of human protease-activated receptor 1. Nature 492:387-392

Zhou Y, Morais-Cabral JH, Kaufman A, MacKinnon R (2001) Chemistry of ion coordination and hydration revealed by a $\mathrm{K}+$ channel-Fab complex at 2.0. A resolution. Nature 414:43-48

Zhu J (2012) Mammalian cell protein expression for biopharmaceutical production. Biotechnol Adv 30:1158-1170 